\title{
EXHIBITION OF THE MOROCCAN RED CRESCENT AT CASTIGLIONE MUSEUM
}

The Red Cross Museum at Castiglione is at present the scene of an exhibition of the Moroccan Red Crescent. Among the features of the exhibition are displays depicting the main activities of this National Society, those of its Central Committee and the more individualized ones of its local committees. Visitors to the museum can also see Moroccan craftsmen at work, together with the colourful and picturesque finished works of art which the craftsmen themselves present to the public. The exhibition was organized to celebrate the twentieth anniversary of the founding of the Moroccan Red Crescent.

The inaugural ceremony was held on 19 June, attended by Mr. Emilio Ondei, Chairman of the Museum's Management Board; Mr. Ezio Mutti, the Director; Mr. Pierre Gaillard, ICRC Adviser and Vice-President of the Museum, who represented our organization; and Mr. L. Akerhielm, representing the Henry-Dunant Institute and the League of Red Cross Societies. The first vice-president of the Moroccan Red Crescent, Mr. A. Bouachrine, gave the opening address, and expressed the apologies of H.R.H. Princess Lalla Malika, President of the National Society, who had been unable to travel to Italy for the occasion. Mr. Pierre Gaillard presented the compliments of the ICRC and its hopes for the success of the exhibition, pointing out that this display by a Red Crescent Society, held in a Red Cross Museum, is a striking example of the unity of our universal movement.

The exhibition of the Moroccan Red Crescent will stay open to the general public until mid-September. 